University of Nebraska - Lincoln

DigitalCommons@University of Nebraska - Lincoln

Reproductive Health of Bass in the Potomac, USA, Drainage: Part

1. Exploring the Effects of Proximity to Wastewater Treatment Plant Discharge

Luke R. Iwanowicz

U.S. Geological Survey, liwanowicz@usgs.gov

Vicki S. Blazer

U.S. Geological Survey

Christopher P. Guy

U.S. Fish and Wildlife Service, chris_guy@fws.gov

Alfred E. Pinkney

U.S. Fish and Wildlife Service, fred_pinkney@fws.gov

John E. Mullican

Inland Fisheries Management Division

See next page for additional authors

Follow this and additional works at: https://digitalcommons.unl.edu/usgsstaffpub

Iwanowicz, Luke R.; Blazer, Vicki S.; Guy, Christopher P.; Pinkney, Alfred E.; Mullican, John E.; and Alvarez, David A., "Reproductive Health of Bass in the Potomac, USA, Drainage: Part 1. Exploring the Effects of Proximity to Wastewater Treatment Plant Discharge" (2009). USGS Staff -- Published Research. 550. https://digitalcommons.unl.edu/usgsstaffpub/550

This Article is brought to you for free and open access by the US Geological Survey at DigitalCommons@University of Nebraska - Lincoln. It has been accepted for inclusion in USGS Staff -- Published Research by an authorized administrator of DigitalCommons@University of Nebraska - Lincoln. 


\section{Authors}

Luke R. Iwanowicz, Vicki S. Blazer, Christopher P. Guy, Alfred E. Pinkney, John E. Mullican, and David A. Alvarez 


\title{
REPRODUCTIVE HEALTH OF BASS IN THE POTOMAC, USA, DRAINAGE: PART 1. EXPLORING THE EFFECTS OF PROXIMITY TO WASTEWATER TREATMENT PLANT DISCHARGE
}

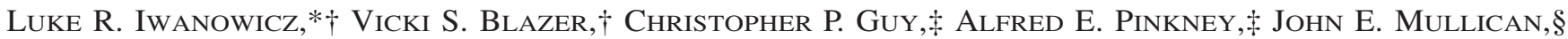 \\ and David A. Alvarez\| \\ $\dagger$ National Fish Health Research Laboratory, U.S. Geological Survey, 11649 Leetown Road, Kearneysville, West Virginia 25430 \\ ¥U.S. Fish and Wildlife Service, Chesapeake Bay Field Office, 177 Admiral Cochrane Drive, Annapolis, Maryland 21401 \\ $\S$ Maryland Department of Natural Resources Fisheries Service, Inland Fisheries Management Division, 10932 Putman Road, \\ Thurmont, Maryland 21788, USA \\ |UU.S. Geological Survey, Columbia Environmental Research Center, 4200 New Haven Road, Columbia, Missouri 65201
}

(Received 8 September 2008; Accepted 26 November 2008)

\begin{abstract}
Intersex (specifically, testicular oocytes) has been observed in male smallmouth bass (SMB; Micropterus dolomieu) and other centrarchids in the South Branch of the Potomac River, USA, and forks of the Shenandoah River, USA, during the past five years. This condition often is associated with exposure to estrogenic endocrine-disrupting chemicals in some fish species, but such chemicals and their sources have yet to be identified in the Potomac. In an attempt to better understand the plausible causes of this condition, we investigated the reproductive health of bass sampled up- and downstream of wastewater treatment plant (WWTP) effluent point sources on the Potomac River in Maryland, USA. Smallmouth bass were sampled from the Conococheague Creek and the Monocacy River, and largemouth bass (LMB; Micropterus salmoides) were collected near the Blue Plains WWTP on the mainstem of the Potomac River. Chemical analyses of compounds captured in passive samplers at these locations also were conducted. A high prevalence of intersex (82-100\%) was identified in male SMB at all sites regardless of collection area. A lower prevalence of intersex (23\%) was identified in male LMB collected at the Blue Plains site. When up- and downstream fish were compared, significant differences were noted only in fish from the Conococheague. Differences included condition factor, gonadosomatic index, plasma vitellogenin concentration, and estrogen to testosterone ratio. In general, chemicals associated with wastewater effluent, storm-water runoff, and agriculture were more prevalent at the downstream sampling sites. An exception was atrazine and its associated metabolites, which were present in greater concentrations at the upstream sites. It appears that proximity to effluent from WWTPs may influence the reproductive health of bass in the Potomac watershed, but inputs from other sources likely contribute to the widespread, high incidence of testicular oocytes.
\end{abstract}

Keywords-Smallmouth bass Endocrine disruption Potomac Intersex

\section{INTRODUCTION}

During 2003, a high prevalence of interex (33-80\%; specifically, testicular oocytes [TOs]), was identified in male smallmouth bass (SMB; Micropterus dolomieu) collected from numerous sites within the South Branch of the Potomac River (WV, USA). Subsequent surveys of SMB in a regionally distinct section of the Potomac River drainage (the Shenandoah River, VA, USA) revealed an even higher prevalence of TOs (80$100 \%$ ) than found in the South Branch [1]. The observation of TOs in gonochoristic fish is not an unprecedented finding in wild fish, but it is uncommon and, therefore, is frequently used as a biomarker of exposure to estrogenic endocrine-disrupting chemicals (EDCs) [2-4]. Thus, the apparent widespread prevalence of this condition in the Potomac River drainage suggests the presence of biologically relevant point and nonpoint sources of these chemical compounds. Interestingly, given that other centrarchids, such as largemouth bass (LMB; Micropterus salmoides), at these sites have a lower prevalence of TOs compared with SMB (unpublished data from our laboratory), SMB may be particularly sensitive to exposure to putative EDCs. Currently, however, the causes for the condition and presence of other adverse responses are unknown.

* To whom correspondence may be addressed (liwanowicz@usgs.gov).

Published on the Web 12/22/2008.

Any use of trade, product, or firm names is for descriptive purposes only and does not imply endorsement by the U.S. Government.
The Potomac River basin is located in four U.S. mid-Atlantic states (MD, PA, VA, and WV) and the District of Columbia, and it is the second largest tributary of the Chesapeake Bay. The basin encompasses more than $23,600 \mathrm{~km}^{2}$ and receives effluent from multiple industrial sources and urban combined sewer overflows as well as from nonpoint sources [5]. Wastewater treatment plants (WWTPs) are included as contributors of point-source effluent into this system. Though not previously examined in the Potomac River basin, WWTPs are recognized as a general source of EDCs. Examples include both natural and synthetic substances, such as polychlorinated biphenyls, phthalates, pesticides, heavy metals, alkylphenols, polycyclic aromatic hydrocarbons, 17 $\beta$-estradiol, $17 \alpha$-ethinylestradiol, and bisphenol A [6-8] (http://coastalscience. noaa.gov/documents/techmemo149.pdf). Treatment of wastewater before discharge differs between WWTPs, and not all of the common strategies effectively remove EDCs. Consequently, different WWTPs vary in their ability to remove particular classes of EDCs $[9,10]$.

Wastewater treatment plants are only one potential source of chemicals that may adversely affect the general and reproductive health of fish. Runoff from agricultural land has been shown to contain hormones and pharmaceutical chemicals [11,12]. Additionally, pesticides and herbicides applied on agricultural, public, and residential lands are transported to aquatic ecosystems during rain events $[13,14]$. Leachates from landfills [15], polychlorinated biphenyls $[16,17]$, polycyclic aro- 
Table 1. Water-quality parameters at collection sites within the Potomac (USA) drainage measured at the time of fish collections

\begin{tabular}{|c|c|c|c|c|c|}
\hline \multirow[b]{2}{*}{ Site } & \multicolumn{5}{|c|}{ Water-quality parameter } \\
\hline & $\begin{array}{c}\text { Temperature } \\
\left({ }^{\circ} \mathrm{C}\right)\end{array}$ & $\begin{array}{l}\text { Conductivity } \\
(\mathrm{mS} / \mathrm{cm})\end{array}$ & $\begin{array}{l}\text { Dissolved oxygen } \\
(\mathrm{mg} / \mathrm{L})\end{array}$ & $\begin{array}{c}\% \text { Dissolved oxygen } \\
\text { saturation }\end{array}$ & $\mathrm{pH}$ \\
\hline Conococheague, upstream & 21.1 & 0.511 & 7.1 & 77.4 & 6.5 \\
\hline Conococheague, downstream & 21.7 & 0.441 & 9.0 & 101.4 & 7.3 \\
\hline Monocacy, upstream & 23.1 & 0.365 & 10.9 & 124.2 & 7.0 \\
\hline Monocacy, downstream & 21.8 & 0.487 & 10.5 & 117.2 & 7.0 \\
\hline Blue Plains & 25.8 & 0.615 & 6.8 & 100.0 & 6.8 \\
\hline
\end{tabular}

matic hydrocarbons [18,19], and other compounds from industrial effluents, atmospheric deposition, spills, and storm-water runoff also contribute endocrine-modulating chemicals to the aquatic environment.

Intersex may be used as biomarker of reproductive health, but other bioindicators of reproductive health in fish populations are frequently evaluated as well. Examples include morphological indicators, such as changes in gonadosomatic index (GSI) and secondary sex characteristics [20,21]. Histologic observations within the gonads such as atresia, foci of pigmented cells, and gamete stage also are useful [22]. Lastly, physiological measures of plasma vitellogenin (VTG) [23] and sex steroid hormone concentrations are common endpoints of endocrine disruption [24,25].

Here, we present the results of a study designed to investigate the reproductive health of bass inhabiting waters near three WWTPs. The primary goals of this research were to further evaluate the extent of reproductive abnormalities in bass within the Potomac drainage and to investigate potential causes of the high prevalence of TOs and other adverse effects using a suite of biological endpoints. A companion study [26] quantified the presence of polar and nonpolar waterborne chemical contaminants and their in vitro estrogenicity to define the differences in chemical fingerprints between the sample locations.

\section{MATERIALS AND METHODS}

\section{Sampling sites}

A list of the 66 major WWTPs, defined as those with capacity of more than 0.5 million gallons per day (mgd; $1 \mathrm{mgd}$ $=3.78$ million liters per day), in the Maryland (USA) and Washington, DC, portions of the Potomac watershed was generated and reviewed. Site selection was governed by the principle criteria that bass were present, that they could be collected without adversely affecting the local populations, and that collection could occur immediately downstream and at least $15 \mathrm{~km}$ upstream of a WWTP. Sites along Conococheague Creek and the Monocacy River were selected because they conformed best to these criteria. Water temperatures ranged from 21.1 to $23.1^{\circ} \mathrm{C}$ at the four tributary sites and was $25.8^{\circ} \mathrm{C}$ at the lower mainstem site. All water-quality parameters (Table 1) were similar among sites and within acceptable ranges for bass growth, survival, and health [27].

Conococheague Creek (Fig. 1A) originates north of Chambersburg (PA, USA) and flows through Fairview (MD, USA; site of a U.S. Geological Survey [USGS] gauging station, 01614500) and into the Potomac River at Williamsport in Washington County (MD, USA). Land use within the $911-\mathrm{km}^{2}$ watershed is agricultural (61\%), forested (34\%), and urban (5\%). The estimated minimum baseflow for $7 \mathrm{~d}$ over a 10 -year period (7Q-10) for Conococheague Creek, using data from the nearest
USGS gauging station, is $40.1 \mathrm{mgd}$ [28] (www.mde.state.md. us/assets/document/ConocoTech_Memo\%20Final.pdf). The discharge flow of the WWTP (Fig. 1B), which uses a modified Ludzack-Ettinger treatment process, is $4.1 \mathrm{mgd}$, or approximately $10 \%$ of the minimum baseflow at the downstream site. Agricultural runoff is the primary anthropogenic input at the upstream site. A privately owned structure, Kemps Mill Dam, is located immediately upstream of the WWTP outfall. This structure is considered to be a major impediment to upstream fish migration.

The Monocacy River (Fig. 1A) is approximately $93 \mathrm{~km}$ in length and forms near the Maryland and Pennsylvania (USA) border. From there, it flows south between Frederick and Carroll counties (MD, USA), through the City of Frederick (MD, USA), and into the Potomac River. Approximately $60 \%$ of the Monocacy watershed is agricultural, $33 \%$ forested, and 7\% urban. Two WWTPs are suspected to influence the selected downstream Monocacy site (Fig. 1B). The larger is the Frederick WWTP plant, which uses the anaerobicanoxic-aerobic treatment process and has an average daily flow capacity of $8.0 \mathrm{mgd}$. The Fort Detrick (MD, USA) WWTP has a discharge flow of $1.0 \mathrm{mgd}$ [29]. Fish collections for this site occurred from the outflow of the Frederick WWTP to approximately $1.5 \mathrm{~km}$ downstream. Although a 7Q-10 is not available for the Monocacy River at this site, a USGS gauging station (01643000) is located just upstream [30] (http://nwis.waterdata.usgs.gov/md/nwis/annual). A conservative estimated contribution of a $1.4 \%$ volume of stream flow from these two WWTPs was determined by dividing their combined maximum discharge rates by the annual flow rate for 2005. Average annual flow was calculated using historical flow rates measured at this gauging station. In drought years, such as 2002, the contribution to stream flow by these WWTPs may approximate $4 \%$ volume. The upper Monocacy River site is influenced primarily by agriculture, similar to the upper Conococheague Creek site.

A site at the Blue Plains WWTP in Washington, DC (Fig. 1A), also was selected for sampling, because it is the largest plant in the Potomac River watershed and the world's largest advanced (tertiary) WWTP. It serves the District of Columbia as well as Montgomery and Prince George counties in Maryland and Fairfax and Loudon counties in Virginia, and it has a design capacity to treat $370 \mathrm{mgd}$ [31] (http://www.dcwasa. com/about/facilities.cfm). The percentage effluent during baseflow conditions could not be estimated, because the area is in the tidal region of the Potomac River and no USGS stream gauges were located nearby.

\section{Fish collections}

Bass were collected by boat or barge electrofishing between September 6 and 14, 2005. This time marks the seasonal onset 

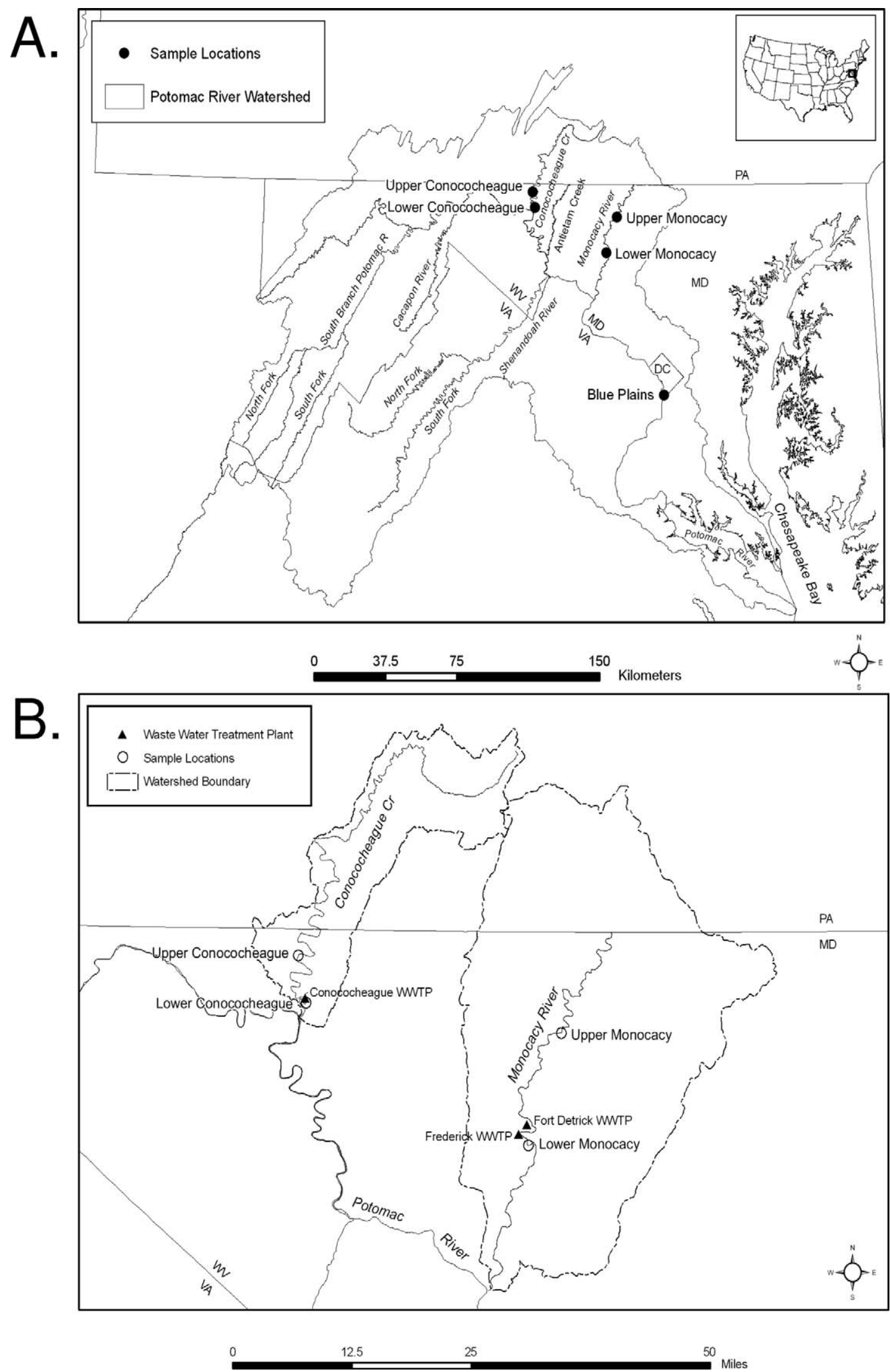

Fig. 1. (A) Collection site locations (USA) for smallmouth bass (Micropterus dolomieu) and largemouth bass (Micropterus salmoides) within the Potomac drainage. (B) Sample locations in special reference to wastewater treatment plants (WWTPs). 
of reproductive recrudescence. Collections would have less impact on the population at this time than during the spring, when nest-building and spawning occurs, and the data could be compared to those of other field studies that assessed reproductive health of bass and were conducted in the fall [32-36]. Thirty mature bass (total length, $>200 \mathrm{~mm}$ ) were collected at each site in an attempt to obtain 10 males and 10 females. Smallmouth bass were collected at the sites on Conococheague Creek and the Monocacy River. Because no SMB were caught on the mainstem site of the Potomac near the Blue Plains plant, LMB were collected at this site (Fig. 1). Largemouth bass were only captured downstream of the Blue Plains site. Fish collected at the downstream WWTPs and Blue Plains were collected within $1 \mathrm{~km}$ of the discharge. Upstream and downstream sites on the same river were separated by at least $15 \mathrm{~km}$.

Fish were killed with a lethal dose of tricaine methane sulfonate (Finquel ${ }^{\circledR \times}$; Argent), weighed on a portable scale to the nearest $0.1 \mathrm{~g}$, and measured for total length to the nearest millimeter. Gonads and livers were weighed on an analytical balance with a calibrated tolerance of $0.01 \mathrm{~g}$. Blood was drawn from the caudal vein with a heparinized syringe, transferred to vacutainers containing $62 \mathrm{U}$ of sodium heparin (Fisher Scientific), and stored on wet ice. Blood was centrifuged for 10 min at $1,000 \mathrm{~g}$ and $4^{\circ} \mathrm{C}$ to hasten plasma separation within 3 $\mathrm{h}$ of collection. Plasma was removed, aliquoted into cryovials, and stored at $-80^{\circ} \mathrm{C}$ until assayed for VTG and reproductive hormones.

A necropsy-based assessment similar to that described by Schmitt et al. [37] accompanied the sample collection. Grossly visible lesions and abnormalities were recorded. Gonads were removed and weighed for GSI determination as follows:

$$
\text { [gonad wt/(body wt }-\operatorname{gonad} w t)] \cdot 100
$$

Gonads were fixed in Z-fix (Anatech LTD) for histological evaluation. Otoliths were removed from the SMB and used for age determination [38].

\section{Histopathological and biochemical procedures}

Fixed gonads were dehydrated in alcohol, infiltrated with paraffin, sectioned at a thickness of $6 \mu \mathrm{m}$, and stained with hematoxylin and eosin [39]. Gonad sections were examined microscopically and staged, and any abnormalities were ranked from 0 to 4 (absent to severe) as described by Blazer [22]. Individual oocyte were staged as follows: Stage 1, immature (nucleolar); stage 2, early vitellogenic (corticol alveolar); stage 3 , midvitellogenic (yolk droplet); stage 4, mature (yolk hydrates); and stage 5, postovulatory follicles. The stage for an ovary was based on the most prevalent oocyte stage present. At least five sections along the ovary were examined. The percentage of atretic eggs was determined by counting 200 oocytes and calculating the percentage of degenerating or necrotic oocytes. At least five pieces along the length of the testes were sectioned, and TO prevalence and severity were scored as described by Blazer et al. [1]. Male gonad stage was scored as follows: Stage 1, predominantly spermatogonia or spermatocytes; stage 2, approximately equal portions of spermatocytes, spermatids, and spermatozoa; stage 3, primarily spermatozoa; and stage 4, postspawn.

Plasma VTG concentrations were measured using a direct enzyme-linked immunosorbent assay (ELISA) with monoclonal antibody 3G2 and were carried out at the Center for Human and Environmental Toxicology, University of Florida (Gainesville, FL, USA), as described by Denslow et al. [40]. Con- centrations of the unknowns were determined from the standard curves and using the Softmax Pro TM Program (Molecular Devices). The limit of detection was $0.001 \mathrm{mg} / \mathrm{ml}$. Intraand interassay variability were less than $10 \%$.

Plasma hormone concentrations (17 $\beta$-estradiol and testosterone) were measured using radioimmunoassay according to the method described by Sower and Schreck [41]. Briefly, plasma samples were extracted twice in a 10-fold excess of diethyl ether, blown to dryness, and solubilized in $200 \mu \mathrm{l}$ of room-temperature Dulbecco's phosphate-buffered saline (Sigma-Aldrich) containing $0.1 \%$ knox gelatin (PG). One hundred microliters of antiestradiol antiserum (anti-17 $\beta$-estradiol Ab244 anti-estradiol-6-BSA; Gordon Niswender) diluted 1:65,000 in PG buffer or antitestosterone antiserum (R156/7; Coralie Munroe) diluted 1:30,000 in PG buffer were added to each sample tube, vortexed, and incubated at room temperature for $30 \mathrm{~min}$. The same volume of PG buffer was added to tubes designated to determine nonspecific background and total counts per minute (CPM). Following incubation, $100 \mu \mathrm{l}$ of tritiated $17 \beta$-estradiol or testosterone $(5,000$ CPM in PG buffer) were added to all tubes, vortexed, and incubated at room temperature for 60 or $30 \mathrm{~min}$, respectively. Samples were immediately cooled in an ice bath for $30 \mathrm{~min}$, and $500 \mu \mathrm{l}$ of icecold charcoal-dextran solution $(0.63 \%$ alkaline charcoal and $0.4 \%$ dextran in PG buffer) were added. Samples were vortexed, incubated on ice for $15 \mathrm{~min}$, and centrifuged at 2,200 $g$ for $20 \mathrm{~min}$ at $4^{\circ} \mathrm{C}$. The supernatant was then decanted into scintillation vials containing $4 \mathrm{ml}$ of OptiPhase HiSafe 2 scintillation fluid (PerkinElmer) and mixed by inversion. Sample CPM was measured using a Tri Carb liquid scintillation counter (PerkinElmer), and mean sample CPM was determined over an 8-min integration time. All samples were run in duplicate, and plasma steroid values were interpolated from a standard curve using curve-fitting algorithms in Prism for Windows ${ }^{\circledR}$ (Ver 4.03; GraphPad Software). Standard curves consisted of nine dilutions of 17 $\beta$-estradiol (E0950-000; Steraloids) or testosterone (A6950-000; Steraloids). Sample values were rejected and reevaluated if the coefficient of variation between duplicate tubes exceeded $10 \%$.

\section{Data analysis}

Before comparative statistical analyses, all data were tested for normality using the Shapiro-Wilks $W$ test and for homogeneity of variance with Levene's test. Given that all data did not conform to the assumptions of parametric statistics, the conservative, nonparametric Kruskal-Wallis test was selected. Data from the Blue Plains site were not included in statistical analyses, because LMB rather than SMB were collected. Differences in the prevalence of male bass with intersex and fish with measurable VTG were analyzed using Fisher's exact test. All statistical analyses were performed using SyStat ${ }^{\circledR} 11$ for Windows (SyStat Software). Differences were considered to be significant when $p<0.05$.

\section{RESULTS}

\section{Morphometric and fish health indicators}

At both Conococheague sites, an equal number of male and female SMB were collected. Only seven males were obtained at the Monocacy lower site, despite sampling 30 fish. At the upstream site, one male fish was misidentified as a female in the field; hence, unequal numbers were sampled. At the mainstem site, only seven LMB females were collected (Tables 2 and 3). 
Table 2. Morphometric results for female bass from collection sites within the Potomac (USA) drainage ${ }^{\mathrm{a}}$

\begin{tabular}{lrllll}
\hline Site & $n$ & Length $(\mathrm{mm})$ & Weight $(\mathrm{g})$ & Age & Condition factor \\
\hline Conococheague, upstream & 10 & $321 \pm 17.3 \mathrm{~A}$ & $484.3 \pm 87.0 \mathrm{~A}$ & $3.6 \pm 0.5 \mathrm{~A}$ & $1.35 \pm 0.03 \mathrm{~A}$ \\
Conococheague, downstream & 10 & $261 \pm 8.8 \mathrm{~B}$ & $233.2 \pm 27.0 \mathrm{~B}$ & $3.1 \pm 0.2 \mathrm{~A}$ & $1.27 \pm 0.03 \mathrm{~A}$ \\
Monocacy, upstream & 9 & $271 \pm 18.8$ & $284.2 \pm 61.8$ & $2.6 \pm 0.4$ & $1.26 \pm 0.03$ \\
Monocacy, downstream & 13 & $269 \pm 14.2$ & $280.0 \pm 51.0$ & $2.7 \pm 0.4$ & $1.27 \pm 0.04$ \\
Blue Plains & 7 & $370 \pm 21.1$ & $831.4 \pm 180.5$ & ND & $1.48 \pm 0.01$ \\
\hline
\end{tabular}

${ }^{a}$ Data are presented as the mean \pm standard error. Values followed by different uppercase letters indicate that the upstream and downstream sites are significantly different (Kruskal-Wallis test, $p<0.05$ ). ND $=$ no data available.

Female SMB collected at the upstream Conococheague site were larger ( $p=0.008)$, but not statistically older, than those collected downstream. Female bass collected at the upstream and downstream sites on the Monocacy were similar in size, age, and condition factor (Table 2). The LMB collected at the Blue Plains (mainstem of the Potomac River) site were larger than the SMB collected from the Conococheague or Monocacy rivers; unfortunately, their age was not determined.

Male SMB collected upstream on the Conococheague were heavier, with a significantly ( $p=0.009$ ) higher median condition factor and approximately the same age as those collected downstream. On the Monocacy, the males downstream were similar in size (length and weight), had a similar condition factor, but were significantly older than those collected at the upstream site (Table 3).

\section{Reproductive indicators}

All fish collected were sexually mature. The median GSI of female SMB collected at the upstream Conococheague site was approximately double and significantly $(p=0.005)$ higher than that of females from the downstream site (Table 4). Vitellogenin ranged from not detected (ND) to $3.378 \mathrm{mg} / \mathrm{ml} \mathrm{up}$ stream and from ND to $0.802 \mathrm{mg} / \mathrm{ml}$ downstream, and it was detected in 8 of 10 females $(80 \%)$ at each site. The median VTG concentration in downstream females was significantly ( $p=0.003$ ) lower than that of fish collected upstream (Table 4). This coincided with $90 \%$ of the female gonads collected at the upstream site being at stage 2, whereas only $60 \%$ of the downstream gonads were at stage 2 (Fig. 2A). The remaining 10 and $40 \%$ of ovaries, respectively, contained oocytes at stage 1 (Fig. 2B). Atretic follicles (Fig. 2C) were present in females from both collection sites. The average percentage atretic follicles per ovary was $8.6 \%$ (standard deviation $[\mathrm{SD}]=4.9 \%$ ) and $4.2 \%$ ( $\mathrm{SD}=4.1 \%$ ) for females collected at the up- and downstream sites, respectively.

On the Monocacy, the median GSI of the upstream and downstream female SMB was similar. Only $56 \%$ of the female SMB collected upstream and $77 \%$ of those collected downstream had measurable VTG, and no significant difference was found in concentrations between sites. Those collected down- stream, however, had only $32 \%$ (or $21 \%$ if using the mean of only those with measurable levels) of the amount of those collected upstream. Ovaries with stage 2 oocytes were observed in 77 and $85 \%$ of the females collected at the upstream and downstream sites, respectively. The average percentage atretic follicles per ovary was $3.8 \%(\mathrm{SD}=4.2 \%)$ and $6.0 \%$ $(\mathrm{SD}=5.4 \%)$ for females collected at the up- and downstream sites, respectively.

At the mainstem site, the mean GSI of the female LMB was the lowest observed (i.e., 0.43), and though $100 \%$ had measurable VTG, the mean concentration was lower than that measured in SMB at the two upstream sites (Table 4). All female gonads collected at this site were stage 1 .

Male SMB collected at the upstream site on the Conococheague had approximately triple the GSI of those collected downstream. Sixty percent of the upstream male bass had measurable VTG (range, ND to $0.337 \mathrm{mg} / \mathrm{ml}$ ), whereas $90 \%$ of the male downstream SMB had circulating VTG (range, ND to $0.306 \mathrm{mg} / \mathrm{ml})$. All testes $(100 \%)$ were at stage 2 at the upstream site. Downstream, however, only $60 \%$ male gonads were at this stage, and the remaining $40 \%$ were stage 1 . No significant difference was found in the mean concentration of plasma VTG, but the mean concentration in the upstream bass was more than double that of those collected downstream (Table 5). No statistical difference ( $p=0.303$ ) was found in the number of males with detectable VTG. A high percentage of SMB with TOs (Fig. 2D and Table 2) was observed at both upstream and downstream sites on the Conococheague (100 and $90 \%$, respectively).

On the Monocacy, the upstreams males had a median GSI similar to that of the downstream males (Table 5). Male gonads from the upper Monocacy were predominantly stage 1 (55\%), with the remaining $45 \%$ at stage 2 , whereas testes from the lower site were mostly stage $2(75 \%)$, with $25 \%$ at stage 1 . Vitellogenin was observed in $45 \%$ of male SMB collected upstream (range, ND to $0.081 \mathrm{mg} / \mathrm{ml}$ ) and in $33 \%$ of those collected downstream (range, ND to $0.278 \mathrm{mg} / \mathrm{ml}$ ), and 80 and $100 \%$, respectively, had TOs. Eighty-five percent of the LMB collected at the Blue Plains site had measurable VTG, and the mean VTG concentration at this site was the highest measured.

Table 3. Morphometric results of male bass from collection sites within the Potomac (USA) drainage

\begin{tabular}{|c|c|c|c|c|c|}
\hline Site & $n$ & Length $(\mathrm{cm})$ & Weight (g) & Age & Condition factor \\
\hline Conococheague, upstream & 10 & $292 \pm 12.7 \mathrm{~A}$ & $342.7 \pm 40.2 \mathrm{~A}$ & $2.9 \pm 0.3 \mathrm{~A}$ & $1.33 \pm 0.03 \mathrm{~A}$ \\
\hline Conococheague, downstream & 10 & $255 \pm 10.4 \mathrm{~A}$ & $207.7 \pm 24.1 \mathrm{~B}$ & $2.6 \pm 0.4 \mathrm{~A}$ & $1.21 \pm 0.03 \mathrm{~B}$ \\
\hline Monocacy, upstream & 11 & $245 \pm 11.3$ & $200.1 \pm 32.0$ & $1.7 \pm 0.2$ & $1.27 \pm 0.02$ \\
\hline Monocacy, downstream & 7 & $264 \pm 10.6$ & $247.2 \pm 28.2$ & $2.6 \pm 0.4$ & $1.22 \pm 0.03$ \\
\hline Blue Plains & 13 & $353 \pm 10.1$ & $743.4 \pm 87.3$ & ND & $1.61 \pm 0.05$ \\
\hline
\end{tabular}

a Data are presented as the mean \pm standard error. Values followed by different uppercase letters indicate that the upstream and downstream sites are significantly different (Kruskal-Wallis test, $p<0.05$ ). ND = no data available. 
Table 4. Gonadosomatic indices (GSI), plasma vitellogenin (VTG), and estrogen to testosterone ratio (E:T) of female bass from collection sites within the Potomac (USA) drainage ${ }^{a}$

\begin{tabular}{lcccc}
\hline Site & GSI & \% Samples with VTG & Plasma VTG (mg/ml) & E:T \\
\hline Conococheague, upstream & $1.26 \pm 0.35 \mathrm{~A}$ & $80 \mathrm{~A}$ & $1.247 \pm 0.485 \mathrm{~A}$ & $0.98 \pm 0.14 \mathrm{~A}$ \\
Conococheague, downstream & $0.63 \pm 0.06 \mathrm{~B}$ & $80 \mathrm{~A}$ & $0.119 \pm 0.105 \mathrm{~B}$ & $0.91 \pm 0.05 \mathrm{~A}$ \\
Monocacy, upstream & $0.94 \pm 0.11 \mathrm{~A}$ & 45 & $1.885 \pm 1.014$ & $0.89 \pm 0.17$ \\
Monocacy, downstream & $0.82 \pm 0.09$ & 77 & $0.395 \pm 0.118$ & $0.95 \pm 0.07$ \\
Blue Plains & $0.43 \pm 0.05$ & 100 & $0.465 \pm 0.251$ & $0.76 \pm 0.09$ \\
\hline
\end{tabular}

${ }^{a}$ Data are presented as the mean \pm standard error. Values followed by different uppercase letters indicate the upstream and downstream sites are significantly different (Kruskal-Wallis or Fisher's exact test, $p<0.05$ ).

${ }^{\mathrm{b}}$ Mean of only those fish with a measurable amount of VTG.

At Blue Plains, in only $23 \%$ was the presence of TO noted (Table 5).

Median plasma estradiol concentrations of the SMB were significantly lower in the male fish at both sites when compared to the female fish. On the Conococheague, the downstream males had approximately double the median plasma estradiol of those upstream, whereas on the Monocacy, upstream and downstream levels were similar. Females on the Conococheague were similar upstream and downstream, whereas on the Monocacy, bass from the downstream site had higher concentrations compared to those in the upstream females. Median male and female estradiol concentrations were similar in the LMB from Blue Plains (Fig. 3).

Median plasma testosterone concentrations of LMB were similar between males and females. On the Conococheague, the upstream males had a lower mean concentration compared with those downstream, as did the females. On the Monocacy, the median concentrations of the upstream and downstream males were similar. The upstream females had a lower concentration than the downstream females (Fig. 4). These differences, however, were not statistically different.
The median estradiol to testosterone ratios $(\mathrm{E}: \mathrm{T})$ of the female SMB were all similar and approximately one; however, the median E:T of the female LMB was lower, at 0.73. Male SMB on both rivers had a higher median E:T downstream than upstream. The SMB males at the downstream sites had an E:T similar to that of the male LMB (Table 5).

\section{DISCUSSION}

Abnormal reproductive physiology resulting from unavoidable exposure to wastewater effluent has been documented in wild fish populations for more than a decade [2,6,42-44]. Although WWTP effluent contains a milieu of biologically active substances, those with estrogenic potential have garnered the most attention from the scientific community $[45,46]$. Numerous plasma-associated physiological measures (i.e., VTG and steroid hormones) have been used as indicators of exposure to estrogenic chemicals. The presence of intersex (principally TOs in males), however, continues to rival these measures, because it appears to be a less transient indicator of estrogenic exposure. Experimental evidence purports that intersex may be induced early in development, during critical

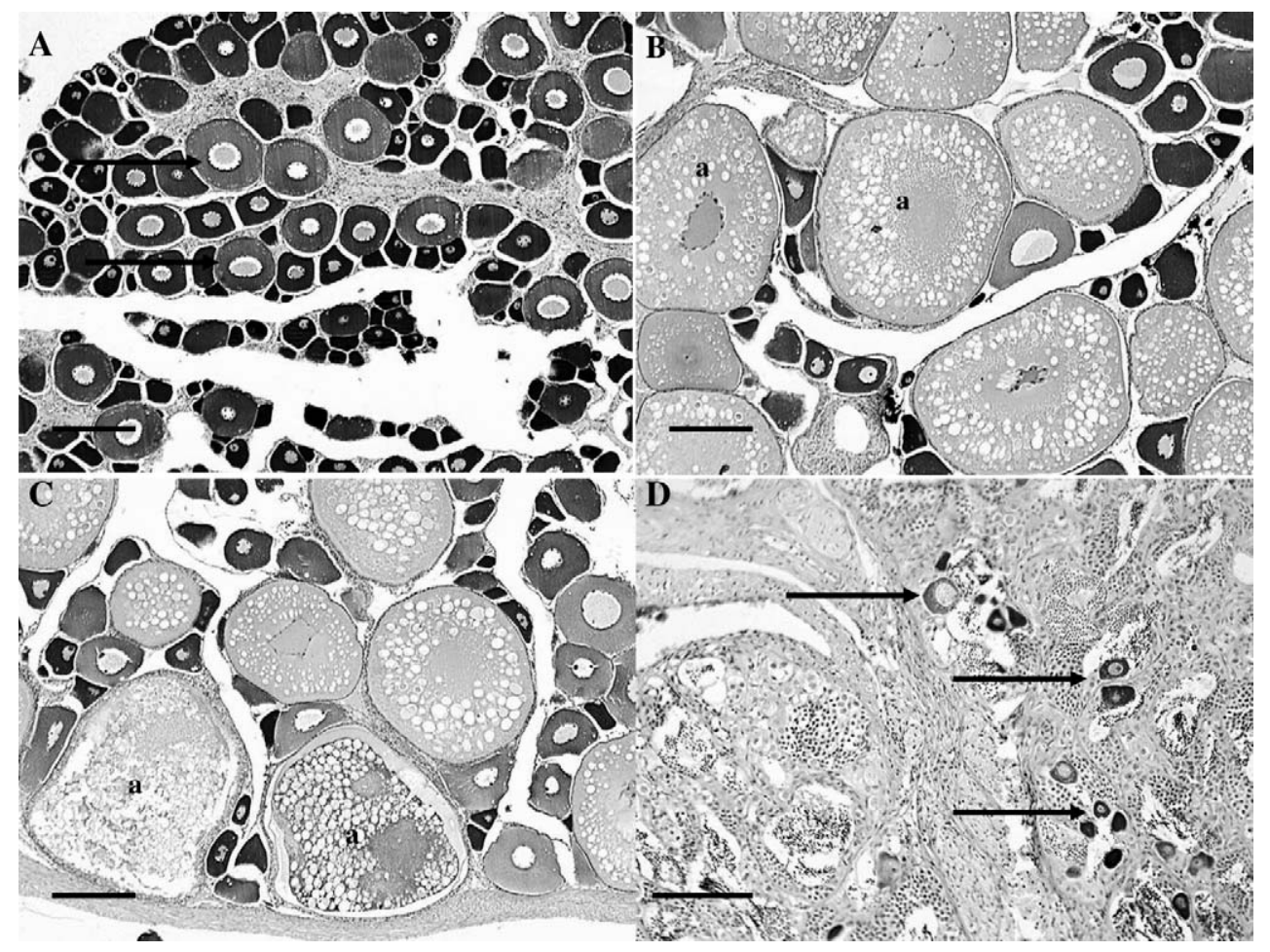

Fig. 2. Microscopic observations in bass gonads. (A) Stage 1 ovary with oocytes that have only progressed to the perinucleolar stage (arrows). (B) Stage 2 ovary containing oocytes that have progressed to the cortical alveolar stage (a). (C) Atretic oocytes (a) within a stage 2 ovary. (D) Oocytes (arrows) within the testis of a bass. Hematoxylin-and-eosin stain; bar $=200 \mu \mathrm{m}($ A-C) and $100 \mu \mathrm{m}(\mathbf{D})$. 
Table 5. Gonadosomatic index (GSI), testicular oocytes (TO), plasma vitellogenin (VTG), and estrogen to testosterone ratio (E:T) ratio of male bass from collection sites within the Potomac (USA) drainage ${ }^{a}$

\begin{tabular}{|c|c|c|c|c|c|c|}
\hline \multirow[b]{2}{*}{ Site } & \multirow[b]{2}{*}{ GSI } & \multicolumn{2}{|r|}{ TO } & \multicolumn{2}{|r|}{ VTG } & \multirow[b]{2}{*}{ E:T } \\
\hline & & $\begin{array}{l}\text { Prevalence } \\
\quad(\%)\end{array}$ & Severity index & $\begin{array}{l}\% \text { Samples } \\
\text { with VTG }\end{array}$ & $\begin{array}{l}\text { Plasma concentration } \\
\qquad(\mathrm{mg} / \mathrm{ml})^{\mathrm{b}}\end{array}$ & \\
\hline Conococheague, upstream & $0.39 \pm 0.06 \mathrm{~A}$ & $100 \mathrm{~A}$ & $2.1 \pm 0.3 \mathrm{~A}$ & $60 \mathrm{~A}$ & $0.117 \pm 0.051 \mathrm{~A}$ & $0.37 \pm 0.10 \mathrm{~A}$ \\
\hline Conococheague, downstream & $0.13 \pm 0.06 \mathrm{~B}$ & $90 \mathrm{~A}$ & $1.8 \pm 0.4 \mathrm{~A}$ & $90 \mathrm{~A}$ & $0.050 \pm 0.036 \mathrm{~B}$ & $0.58 \pm 0.08 \mathrm{~B}$ \\
\hline Monocacy, upstream & $0.30 \pm 0.04$ & 82 & $1.2 \pm 0.3$ & 45 & $0.059 \pm 0.010 \mathrm{~A}$ & $0.46 \pm 0.13$ \\
\hline Monocacy, downstream & $0.30 \pm 0.15$ & 100 & $1.9 \pm 0.3$ & 33 & $0.143 \pm 0.085 \mathrm{~A}$ & $0.51 \pm 0.15$ \\
\hline Blue Plains & $0.06 \pm 0.003$ & 23 & $0.2 \pm 0.2$ & 85 & $0.577 \pm 0.165$ & $0.51 \pm 0.07$ \\
\hline
\end{tabular}

a Data are presented as the mean \pm standard error. Values followed by different uppercase letters indicate the upstream and downstream sites are significantly different (Kruskal-Wallis or Fisher's exact test, $p<0.05$ ).

${ }^{\mathrm{b}}$ Mean of only those fish with a measurable amount of VTG.

stages of sexual differentiation in gonochoristic fish, though exceptions certainly exist. That same research demonstrates that intersex is not induced by similar estrogenic stimuli at later life stages in some species [47]. Interestingly, exposure to estrogenic stimuli later in life may exacerbate the severity of TOs in instances when primary exposure occurred at the critical stages of sexual development [43].

In the present study, estrogenic endocrine disruption, as evidenced by the presence of TOs, was observed at all study sites. The incidence of TOs in male SMB collected from Conococheague Creek and the Monocacy River exceeded $80 \%$, which is higher than that generally observed in SMB from the South Branch of the Potomac but similar to that observed in SMB from the Shenandoah River [1]. When intersex is induced in male SMB from this watershed is not known, but it may occur during critical developmental stages. Male LMB collected at the Blue Plains site had a much lower prevalence of TO compared with that in SMB at the other samples sites. Considering that the Blue Plains site generally had higher levels of most contaminants (Table 6), this may indicate differences in sensitivity to estrogenic chemicals in these closely related species or differences in chemical concentrations among preferential spawning habitat for the two species. Unfortunately, a baseline occurrence of TOs has not been deter- mined for either LMB or SMB. Currently, the best data for SMB is from out-of-basin sites with both low human population and low to moderate agricultural land use, at which 14 to $22 \%$ of male SMB were observed to have TOs [1]. From 1995 to 2004, the USGS conducted fish health assessments, including reproductive endpoints, at large river sites in the Mississippi [32], Rio Grand [33], Columbia [34], Colorado [35], and Savannah, Pee Dee, Mobile, and Apalachicola-Chattahoochee-Flint [36] river basins (all USA). In these studies, LMB and common carp (Cyprinus carpio) were the target species. At a total of 55 sites, LMB males were collected, and at 32 of these sites (58\%), no TOs were reported, suggesting that the baseline prevalence for LMB may be zero. It is interesting that SMB appear to have a fairly high baseline prevalence of this condition. Unfortunately, relatively little information is available regarding sexual development and sex determination in this species. For this reason, it currently is not possible to rule out factors other than, or in addition to, contaminant exposure as contributing to this condition.

The induction of VTG in male fish is perhaps the most frequently applied biomarker of estrogenic exposure, particularly near WWTP discharges [48-51]. Hepatic synthesis of this glycolipoprotein is estrogen dependent. Given the appropriate stimulus, it is produced in females and males alike;

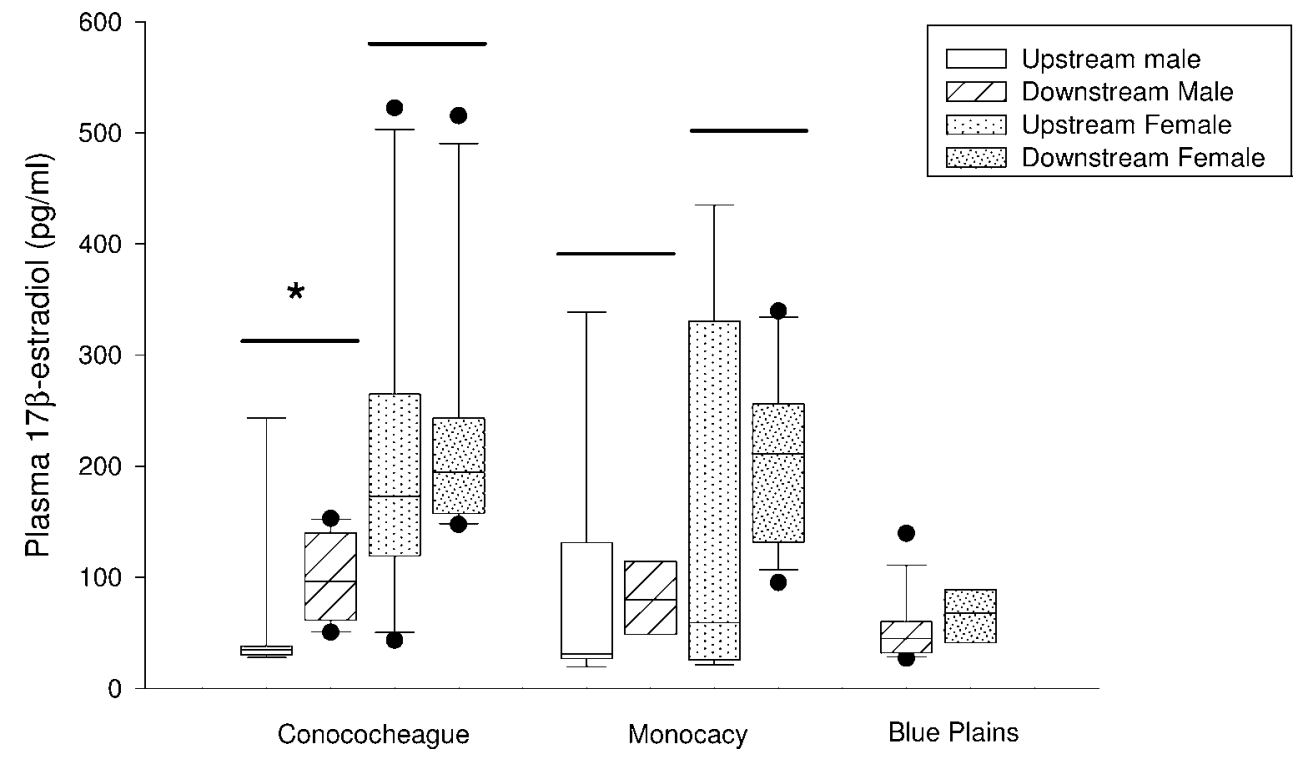

Fig. 3. Plasma $17 \beta$-estradiol concentrations (pg/ml) of smallmouth bass (Micropterus dolomieu) and largemouth bass (Micropterus salmoides). Upstream/downstream pairs marked with an asterisk are significantly different $(p<0.05)$. Dots represent outliers, and whiskers mark the 5th and 95 th percentiles. 


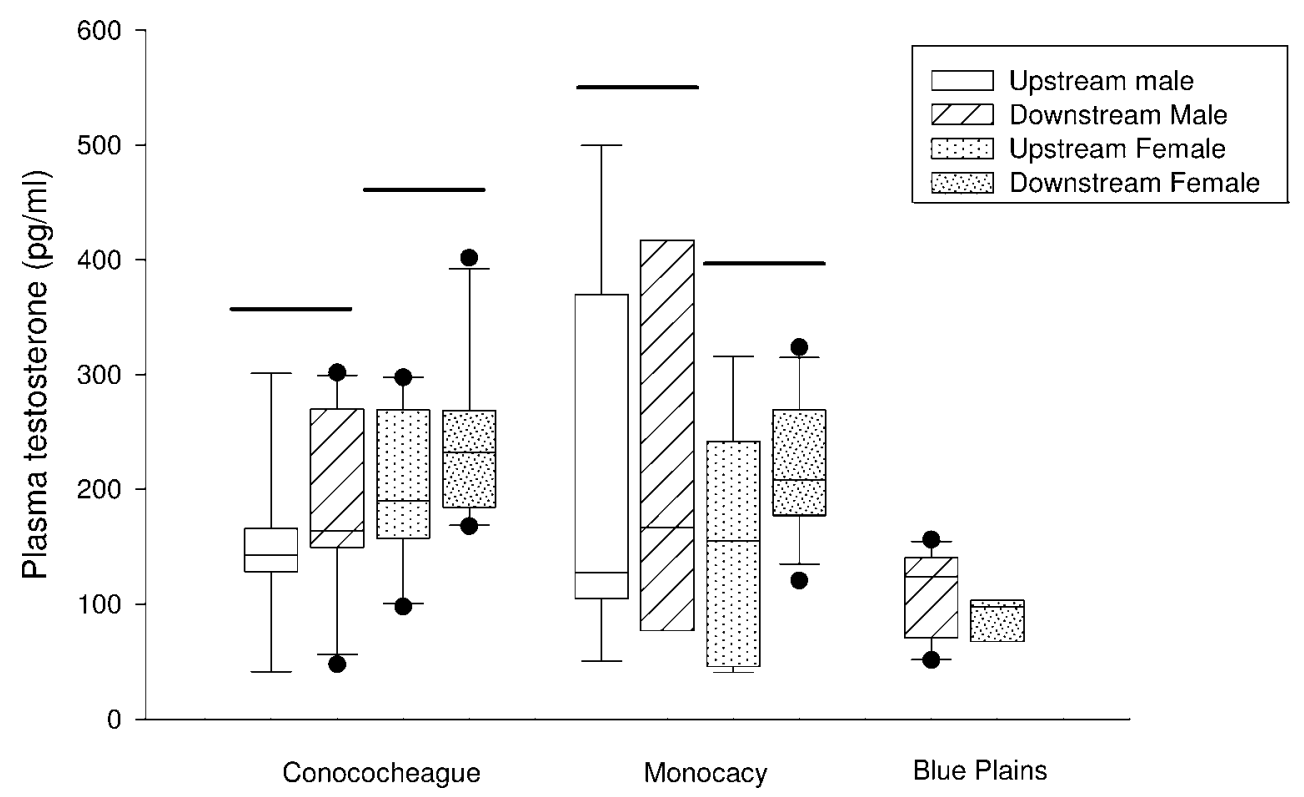

Fig. 4. Plasma testosterone concentrations (pg/ml) in smallmouth bass (Micropterus dolomieu) and largemouth bass (Micropterus salmoides) captured in the vicinity of wastewater treatment facilities. Dots represent outliers, and whiskers mark 5th and 95th percentiles.

however, under normal physiological conditions, males do not produce VTG. Vitellogenin has no known biological function in males, although antimicrobial actions have been suggested [52]. Unlike induction of TOs, the induction of VTG in male fish is rapid, and the protein is detectable in the plasma within days postexposure. Consequently, the presence of plasma VTG is more indicative than TOs of recent and/or continued exposure to estrogenic compounds. In the present study, plasma VTG in male SMB ranged from undetectable to $0.337 \mathrm{mg} / \mathrm{ml}$.
When considering males with measurable VTG, mean concentrations of this protein were highest at the upstream Conococheague and downstream Monocacy sites. These concentrations were considerably lower than those measured in male LMB at the Blue Plains site (Table 5). The significance of elevated concentrations of VTG in these species is unknown, but its presence serves as a useful indication that estrogenic chemicals are present at biologically relevant concentrations. Recently, it has been shown that adverse effects are observed

Table 6. Selected concentrations of chemicals that measured above the method quantitation limit (MQL) in passive sampler extracts ${ }^{\mathrm{a}}$

\begin{tabular}{|c|c|c|c|c|c|}
\hline & \multicolumn{2}{|c|}{ Conococheague } & \multicolumn{2}{|c|}{ Monocacy } & \multirow[b]{2}{*}{ Blue Plains } \\
\hline & Upstream & Downstream & Upstream & Downstream & \\
\hline \multicolumn{6}{|l|}{ Chemical estimated (pg/L) } \\
\hline Total polychlorinated biphenyls & 66 & 215 & $<\mathrm{MQL}$ & 410 & 2,550 \\
\hline Total polyaromatic hydrocarbons & 4,136 & 4,114 & 3,921 & 16,790 & 21,825 \\
\hline Total DDTs ${ }^{\mathrm{b}}$ & 94 & 144 & $<\mathrm{MQL}$ & 655 & 355 \\
\hline Hexachlorobenzene & 83 & 58 & $<\mathrm{MQL}$ & $<\mathrm{MQL}$ & 59 \\
\hline Pentachloranisole & 56 & 225 & 110 & 190 & 310 \\
\hline Lindane & $<\mathrm{MQL}$ & 620 & $<\mathrm{MQL}$ & 550 & $<\mathrm{MQL}$ \\
\hline Total benzenehexachloride ${ }^{c}$ & 89 & 404 & $<\mathrm{MQL}$ & 93 & 218 \\
\hline Chlorpyrifos & $<\mathrm{MQL}$ & 115 & $<\mathrm{MQL}$ & 48 & 475 \\
\hline Total chlordane ${ }^{d}$ & 43 & 136 & 35 & 95 & 620 \\
\hline Dieldrin & 175 & 295 & 104 & 195 & 550 \\
\hline Heptachlor epoxide & $<\mathrm{MQL}$ & 165 & $<\mathrm{MQL}$ & 150 & 405 \\
\hline Endosulfan + endosulfan II & 630 & 1,470 & 830 & 1,330 & 6,050 \\
\hline Metolachlor & 730 & 1,115 & 12,000 & 10,750 & 1,850 \\
\hline Atrazine $^{\mathrm{e}}$ & 90,000 & 46,850 & 88,000 & 44,000 & 30,900 \\
\hline \multicolumn{6}{|c|}{ Wastewater-related chemicals (ng/POCIS) } \\
\hline Celestolide & $<\mathrm{MDL}$ & 130 & $<\mathrm{MDL}$ & $<\mathrm{MDL}$ & 130 \\
\hline Tonalide & $<\mathrm{MDL}$ & 120 & $<\mathrm{MDL}$ & $<\mathrm{MDL}$ & 515 \\
\hline Galaxolide & $<\mathrm{MDL}$ & 335 & $<\mathrm{MDL}$ & 210 & 955 \\
\hline Prometon & 100 & 115 & 100 & $<\mathrm{MDL}$ & 145 \\
\hline Tri(2-chloroethyl)phosphate & $<\mathrm{MQL}$ & 165 & $<\mathrm{MQL}$ & 100 & 360 \\
\hline
\end{tabular}

${ }^{a}$ For more detail, see Alvarez et al. [26]. MDL = method detection limit; POCIS = polar organic chemical integrative sampler.

${ }^{\mathrm{b}}$ Sum of $o, p^{\prime}$-dichlorodiphenyldichloroethylene (DDE), $p, p^{\prime}$-DDE, $o, p^{\prime}$-dichlorodiphenyldichloroethane (DDD), $o, p^{\prime}-\mathrm{DDT}, p, p^{\prime}-\mathrm{DDD}$, and $p, p^{\prime}-$ DDT.

${ }^{c}$ Sum of $\alpha$-benzenehexachloride, $\beta$-benzenehexachloride, and $\delta$-benzenehexachloride.

d Sum of oxychlordane, trans-chlordane, and cis-chlordane.

e Sum of desisoprpylatrazine, desethylatrazine, and atrazine. 
in male fathead minnows (Pimephales promelas) with VTG concentrations of greater than $0.5 \mathrm{mg} / \mathrm{ml}$, but not below this concentration [53]. Only five male LMB from the present study had concentrations exceeding this threshold, and four of these five male LMB (80\%) had levels exceeding $1 \mathrm{mg} / \mathrm{ml}$. Most striking at this site was the observation that males had VTG concentrations comparable to those of females. The detection of measurable VTG in male SMB and LMB indicates that in addition to early life exposure to estrogens (suggested by TOs), these fish also likely are exposed to estrogenic chemicals as adults. The extent and frequency of this exposure is still unknown. Additionally, the kinetics of VTG clearance in bass is unknown. This is of particular importance, because male fish do not appear to have specific mechanisms to excrete VTG [54]. Consequently, VTG remains detectable in the plasma of male fish for weeks to months postexposure $[53,54]$. Thus, in the present study, the presence of VTG may be the result of exposure that occurred weeks to months before our sampling. The observed variability of plasma VTG in male fish includes the possibility of recent immigration of fish from less impacted upstream areas or simply differences in the concentration of chemicals within the river based on flow dynamics. Unfortunately, published home-range studies of SMB in the Potomac drainage are not available; however, home ranges of less than $200 \mathrm{~m}$ have been reported for river systems in Missouri (USA) [55]. Other studies have indicated that some populations/individuals are relatively sedentary and others migratory, and that this may be affected by season [56]. Although our upstream and downstream sites were separated by a much greater distance than the reported home range for some SMB populations, without specific regional data regarding bass movement, we cannot rule out the possibility of some migration between sites. This is less likely on the Conococheague, however, because of the dam immediately upstream of the WWTP outfall.

Species of the genus Micropterus, like most gonochoristic fish, experience an annual reproductive cycle in which recrudescence initiates during the fall and spawning occurs in the spring. Specific dates of these events are governed largely by water temperature and photoperiod. Research conducted on Florida LMB (Micropterus salmoides floridans) maintained in tanks and ponds in Texas (USA) has established the baseline reproductive cycle for this (sub)species. Recrudescence is evident in October through December [57], and peak GSI occurs between late February and late April (immediate prespawn to spawn). The GSI declines rapidly postspawn in May and continues to decrease until reaching a minimum in September. A similar cycle has been documented for hatchery-raised LMB in Florida [58]. In both studies, the GSI was approximately 0.8 to 1.0 in females and 0.1 to 0.2 in males during September (water temperature, $\sim 15^{\circ} \mathrm{C}$ ). In the current study, the mean GSI was 0.4 for female and 0.06 for male LMB. This is considerably lower than the September values reported above; however, this difference probably is the result of the warmer water temperature at the Blue Plains site. The onset of recrudescence at this site likely occurs later in the year, when water temperature decreases. This would explain the low GSI and sex steroid values, which probably were at baseline values during sampling. If this is the case, however, then the presence of VTG in both male and female LMB is likely the result of exposures to estrogens in the water rather than endogenous stimuli. Biological evidence of estrogenic substances in the water at this site is confirmed by results of the bioluminescence yeast estrogen screen conducted by Alvarez et al. [26]. Additionally, concentrations of plasma VTG in male LMB normally are less than $0.05 \mathrm{mg} / \mathrm{ml}$ at any given time during the year [58]. Of particular relevance to the present study, the presence of TOs was not noted in either of the above studies.

Few studies have documented the normal changes in GSI, VTG, or reproductive hormones throughout the reproductive cycle of SMB. The GSI of naturalized lake SMB in Japan is lowest in August and begins to rise during September (water temperature, $\sim 20^{\circ} \mathrm{C}$ ), to 2.0 in females and 0.8 in males [59]. In the present study, fish collected from the downstream Conococheague site had significantly lower GSI compared to fish collected from the upstream Conococheague, both for females and for males ( $p=0.005$ and $p<0.001$, respectively). These sites experience the same photoperiod, and water temperatures are similar (Table 1). The GSIs at this site also were lower than those measured in fish from the Monocacy sites, particularly in the case of males (Table 5). Because water temperature was similar among all sites, chemical exposure from sitespecific inputs is a likely explanation for the delayed onset of spermatogenic recrudescence. The GSI of females collected downstream of the WWTP on the Conococheague was significantly lower than that of females collected upstream, which is consistent with the lower plasma VTG concentrations (Table 4). Again, this observation further corroborates differences in the timing of recrudescence at the lower Conococheague site compared to that upstream. Because VTG production is related to fecundity and egg quality in individual female fish [60,61], the lower concentrations in female bass collected downstream could adversely affect egg quality and subsequent survival of fry. However, because the bass were collected in the fall, either at the onset of or early in recrudescence, further work is required to confidently document reproductive impairment and population-level effects.

Previous research has demonstrated that roach (Rutilus rutilus) exposed to sewage treatment plant effluent had an increased incidence of atresia, decreased estradiol in females, but increased estradiol and testosterone in males [49]. In the current study, differences in steroid hormones were subtle, and significant differences were only observed in males from the Conococheague. Males downstream had significantly ( $p=$ 0.004) higher plasma estradiol concentrations compared with those at the upstream site on the Conococheague. Whereas concentrations of reproductive hormones are useful indicators for disruption of the reproductive cycle [24], these concentrations often are confounded by natural fluctuations and environmental factors, such as water temperature influenced by rain and runoff events [25]. Concentrations of testosterone and estradiol in male SMB have been reported previously at $1 \mathrm{ng}$ / $\mathrm{ml}$ or less during this time of year in Japan. In female SMB, these concentrations are higher, but still less than $2 \mathrm{ng} / \mathrm{ml}$ [59]. These concentrations are considerably higher than those measured at any site during the present study, indicating that SMB in the Potomac watershed initiate recrudescence later in the year. This likely results from geographical differences. To best interpret the significance of different hormone concentrations in these fish, additional multiyear, multiseason data are required to define the normal regional reproductive cycle of SMB.

No individual chemicals were identified as the singular cause of TO and VTG induction in male bass, but a number of EDCs were measured at all sites (Table 6). Passive samplers, both polar organic chemical integrative samplers and semi- 
permeable membrane devices, were deployed at the sites for approximately one month during the sampling period. More detailed information regarding the chemical data is provided by Alvarez et al. [26]. Chemical profiles differed between the sample sites and may be explained, in part, by the type of treatment used at specific plants. This also may have contributed to the biological differences observed between bass collected at the upstream and downstream sites in the Conococheague but in not the Monocacy. For instance, three wastewater-associated chemicals commonly used in fragrances (celestolide, tonalide, and galaxolide) were identified at the downstream site on the Conococheague. Only one of these three chemicals (tonalide) was found at the downstream site on the Monocacy, and none of these three was found at either upstream site. Similarly, tri(2-chloroethyl)phosphate, used in plasticizers and flame retardants, was not found at either upstream site but was measured at both downstream sites, though at a lower concentration on the Monocacy (Table 6). In a study of three WWTPs, Thomas and Foster [62] found that the majority of acidic pharmaceuticals, caffeine, and the antimicrobial triclosan were removed during secondary treatment. The difference in the secondary treatment processes (modified Ludzack-Ettinger [MLE] vs anaerobic-anoxic-aerobic $\left[\mathrm{A}_{2} \mathrm{O}\right]$ ) at the two WWTPs in the present study may explain some of the observed differences. The Conococheague plant uses the MLE process that employs activated sludge consisting of anoxic and oxic phases for biological nutrient reduction, whereas the Frederick WWTP recently upgraded to the $\mathrm{A}_{2} \mathrm{O}$ activated-sludge process that includes an anaerobic phase as well as the anoxic and oxic cycles [63] (http://www.mde.state.md.us/ assets/document/BRF\%20Gannett\%20Fleming-GMB\% 20presentation.pdf). Additional pharmaceuticals may be removed during this phase. In addition, factors such as overall removal efficiencies, operational practices, the nature and concentration of the wastewater influent, and the percentage of river baseflow contributed by effluent may contribute to the differences. Estimated average annual contribution of WWTPs to flow in the Conococheague and Monocacy was approximately 1.1 and $1.4 \%$, respectively. These are annual averages, and times exist when WWTP contribution is higher. In general, however, the percentage contribution is fairly low compared to that in other parts of the country and world where intersex has been identified. That female sex steroids were at or below the method detection limit (see Alvarez et al. [26]) and WWTP contribution to river flow is low suggest other or additional factors as being responsible, in part, for the disrupted reproductive parameters.

Hexachlorobenzene, a chemical that has been shown to alter sex hormone concentrations in crucian carp (Carassius auratus gibelio) [64], was present in the Conococheague but not in the Monocacy. Historically, this chemical was used through the early 1960s as a pesticide to protect the seeds of onions and sorghum, wheat, and other grains against fungus. Currently, hexachlorobenzene is not used commercially in the United States, but it is formed as a by-product during the manufacture of other solvents and some pesticides [65] (http://www.atsdr.cdc.gov/toxprofiles/tp90.pdf). Whereas the presence of hexachlorobenzene is a clear difference between the two rivers, its presence does not explain biological differences in SMB at the up- and downstream sites in the Conococheague. In general, chemical compounds were found at similar or higher concentrations at downstream sites compared to those at upstream sites. The most notable exception was atrazine and its metabolites, which generally were higher at upstream sites, where agricultural input was greatest. Atrazine is a chlorotriazine herbicide used to control annual grasses and broadleaf weeds that is prominently applied where corn is grown. It is associated with intersex and reproductive anomalies in anurans [66]. The exposure of adult fish to atrazine resulted in suppressive effects on plasma androgens and induction of estrogen (both dose and time related) in goldfish [13], but no strong estrogenic effects or overt reproductive toxicity in fathead minnows [67]. To our knowledge, exposure studies during critical periods of sexual differentiation have not been conducted, and it is unknown if atrazine could induce intersex in SMB. The widespread distribution of this herbicide within the Chesapeake watershed [68], however, and particularly the concentrations measured during spring at the current sites [26], may explain the high prevalence of intersex in the Potomac watershed and should be studied in more depth.

Although natural and synthetic estrogens most commonly are associated with the induction of TOs [2-4,47] and VTG in male fish $[23,40,61]$, no steroid hormones were detected in the passive extracts of the present study. It is important to note, however, that the detection limits for $17 \beta$-estradiol and $17 \alpha$-ethinylestradiol were both $2.5 \mathrm{ng} / \mathrm{L}$ [26]. Concentrations of $17 \alpha$-ethinylestradiol as low as $1 \mathrm{ng} / \mathrm{L}$, however, have been shown to induce intersex [69]. A dose-dependent increase in VTG was induced in juvenile zebrafish (Danio rerio) exposed to $2 \mathrm{ng} / \mathrm{L}$ or greater of $17 \alpha$-ethinylestradiol [70], and levels as low as $0.1 \mathrm{ng} / \mathrm{L}$ induced VTG synthesis in immature rainbow trout (Oncorhynchus mykiss) [42]. Thus, that sex steroids were not identified does not imply their absence at biologically relevant concentrations. In fact, estrogenic activity was identified in polar organic chemical integrative samples from all sites using a yeast reporter assay [26]. In short, these findings emphasize the importance of examining both biological and chemical endpoints in field studies, and the potential biological effects of chronic or intermittent exposure to complex chemical mixtures may influence in aquatic organisms.

Based on the physiological and morphological measures, potential adverse effects of WWTP effluent were observed, particularly downstream of the Conococheague WWTP. These included decreased GSI, decreased circulating VTG in female bass, and altered reproductive hormone concentrations. Vitellogenin in male bass and a high prevalence of TO were noted at both upstream and downstream sites, indicating that other sources of endocrine-modulating chemicals, such as agricultural, suburban, and urban runoff, also may influence these populations. In conclusion, though it appears that effluent from some WWTPs may affect the reproductive health of fish in the Potomac watershed, inputs from other sources likely contribute to the widespread, high prevalence of TOs.

Acknowledgement-We appreciate the assistance of Maryland Department of Natural Resources personnel with fish collections, Kathy Spring and Darlene Bowling for histopathology technical assistance, and Leslie Gerlich for producing the maps. We also thank Greg Weber and the U.S. Department of Agriculture, National Center for Cool and Coldwater Aquaculture, for permitting us to use their facility to analyze plasma hormones. The present study was funded by the Division of Environmental Quality of the U.S. Fish and Wildlife Service and by the Chesapeake Bay Priority Ecosystems and Fisheries Programs of the USGS.

\section{REFERENCES}

1. Blazer VS, Iwanowicz LR, Iwanowicz DD, Smith DR, Young JA, Hedrick JD, Foster SW, Reeser SJ. 2007. Intersex (testicular 
oocytes) in smallmouth bass Micropterus dolomieu from the Potomac River and selected nearby drainages. J Aquat Anim Health 19:242-253.

2. Jobling S, Nolan M, Tyler CR, Brightly G, Sumpter JP. 1998. Widespread sexual disruption in wild fish. Environ Sci Technol 32:2498-2506.

3. Jobling S, Williams R, Johnson A, Taylor A, Gross-Sorokin M, Nolan M, Tyler CR, van Aerle R, Santos E, Brighty G. 2006 Predicted exposures to steroid estrogens in UK rivers correlate with widespread sexual disruption in wild fish populations. Environ Health Perspect 114:32-39.

4. Katsu Y, Lange A, Urushitani H, Ichikawa R, Paul GC, Cahill LL, Jobling S, Tyler CR, Iguchi T. 2007. Functional associations between two estrogen receptors, environmental estrogens, and sexual disruption in the roach (Rutilus rutilis). Environ Sci Technol 41:3368-3374.

5. Astin LE. 2007. Developing biological indicators from diverse data: The Potomac Basin-wide index of benthic integrity (B-IBI). Ecol Indic 7:895-908.

6. Pait AS, Nelson JO. 2002. Endocrine disruption in fish: Assessment of recent research and results. NOAA Technical Memorandum NOS NCCOS CCMA 149. NOAA, NOS, Center for Coastal Monitoring and Assessment, Silver Spring, MD, USA.

7. Aguayo S, Muñoz MJ, de la Torre A, Roset J, de la Peña E, Carballo M. 2004. Identification of organic compounds and ecotoxicological assessment of sewage treatment plants (STP) effluent. Sci Total Environ 328:69-81.

8. Nakada N, Nyunoya H, Nakamura M, Hara A, Iguchi T, Takada H. 2004. Identification of estrogenic compounds in wastewater effluent. Environ Toxicol Chem 23:2807-2815.

9. Conn KE, Barber LB, Brown GK, Siegrist RL. 2006. Occurrence and fate of organic contaminants during on-site wastewater treatment. Environ Sci Technol 40:7358-7366.

10. Johnson AC, Williams RJ, Simpson P, Kanda R. 2007. What difference might sewage treatment performance make to endocrine disruption in rivers? Environ Pollut 147:194-202.

11. Hanselman TA, Graetz DA, Wilkie AC. 2003. Manure-borne estrogens as potential environmental contaminants: A review. Environ Sci Technol 37:5471-5478.

12. Soto AM, Calabro JM, Prechtl NV, Yau AY, Orlando EF, Daxenberger A, Kolok AS, Guillette LJ, le Bizec B, Lange IJ, Sonnenschein C. 2004. Androgenic and estrogenic activity in water bodies receiving cattle feedlot effluent in eastern Nebraska, USA. Environ Health Perspect 112:346-352.

13. Spanò L, Tyler CR, van Aerle R, Devos P, Mandiki SNM, Silvestre F, Thomé J-P, Kestemont P. 2004. Effects of atrazine on sex steroid dynamics, plasma vitellogenin concentrations and gonad development in adult goldfish (Carassius auratus). Aquat Toxicol 66:369-379.

14. Lal B. 2007. Pesticide-induced reproductive dysfunction in Indian fishes. Fish Physiol Biochem 33:455-462.

15. Noaksson E, Linderoth M, Tjärnlund U, Balk L. 2005. Toxicological effects and reproductive impairments in female perch (Perca fluviatilis) exposed to leachate from Swedish refuse dumps. Aquat Toxicol 75:162-177.

16. Arukwe A, Yadetie F, Male R, Goksǿyr A. 2001. In vivo modulation of nonylphenol-induced zonagenesis and vitellogenesis by the antiestrogen, 3,3',4,4' -tetrachlorobiphenyl (PCB-77) in juvenile fish. Environ Toxicol Pharmacol 10:5-15.

17. Murphy CA, Rose KA, Thomas P. 2005. Modeling vitellogenesis in female fish exposed to environmental stressors: Predicting the effects of endocrine disturbance due to exposure to a PCB and cadmium. Reprod Toxicol 19:395-409.

18. Nichols J-M. 1999. Vitellogenesis in fish and the effects of polycyclic aromatic hydrocarbon contaminants. Aquat Toxicol 45:7790.

19. Monteiro PRR, Reis-Henriques MA, Coimbra J. 2000. Plasma steroid levels in female flounder (Platichthys flesus) after chronic dietary exposure to single polycyclic aromatic hydrocarbons. Mar Environ Res 49:453-467.

20. Miles-Richardson SR, Kramer VJ, Fitzgerald SD, Render JA, Yamini B, Barbee SJ, Giesy JP. 1999. Effects of waterborne exposure of $17 \beta$-estradiol on secondary sex characteristics and gonads of fathead minnows (Pimephales promelas). Aquat Toxicol 47:129-145.

21. Kleinkauf A, Connor L, Swarbreck D, Levene C, Walker P, Johnson PJ, Leah RT. 2004. General condition biomarkers in relation to contaminant burden in European flounder (Platichthys flesus). Ecotoxicol Environ Saf 58:335-355.

22. Blazer VS. 2002. Histopathological assessment of gonadal tissue in wild fishes. Fish Physiol Biochem 26:85-106.

23. Jones PD, De Coen WM, Tremblay L, Giesy JP. 2000. Vitellogenin as a biomarker for environmental estrogens. Water Sci Technol 42:1-14.

24. Donaldson EM. 1990. Reproductive indices as measures of the effects of environmental stressors in fish. Am Fish Soc Symp 8: 109-122.

25. McMaster ME, Jardine JJ, Ankley GT, Benson WH, Greenley MS Jr, Gross TS, Guillette LJ Jr, MacLatchy DL, Orlando EF, Van der Kraak GJ, Munkittrick KR. 2001. An interlaboratory study on the use of steroid hormones in examining endocrine disruption. Environ Toxicol Chem 20:2081-2087.

26. Alvarez DA, Cranor WL, Perkins SD, Schroeder V, Iwanowicz LR, Clark RC, Guy CP, Pinkney AE, Blazer VS, Mullican J. 2009. Reproductive health of bass in the Potomac, USA, Drainage: Part 2. Seasonal occurrence of persistent emerging organic contaminants. Environ Toxicol Chem 28:1084-1095.

27. Shuter BJ, Ihssen PE, Wales DL, Snucins EJ. 1989. The effects of temperature, $\mathrm{pH}$ and water hardness on winter starvation of young-of-the-year smallmouth bass, Micropterus dolomieui Lacépède. J Fish Biol 35:765-780.

28. Maryland Department of the Environment. 2001. Final technical memorandum for Conococheague Creek BOD TMDL. Baltimore, MD, USA.

29. City of Frederick. 2007. City of Frederick Comprehensive Plan. Community Facilities Element. Frederick, MD, USA.

30. U.S. Geological Survey. 2007. Gaging station database. Reston, WV.

31. DC Water and Sewer Authority. 2007. Facilities Blue Plains Wastewater Treatment Plant. Washington, DC.

32. Schmitt CJ, ed. 2002. Biomonitoring of Environmental Status and Trends (BEST) Program: Environmental contaminants and their effects on fish in the Mississippi River basin. Biological Science Report USGS/BRD/BSR-2002-0004. U.S. Geological Survey, Reston, VA.

33. Schmitt CJ, Hinck JE, Blazer VS, Denslow ND, Dethloff GM, Bartish TM, Coyle JJ, Tillitt DE. 2005. Environmental contaminants and biomarker responses in fish from the Rio Grande and its U.S. tributaries: Spatial and temporal trends. Sci Total Environ 350:161-193.

34. Hinck JE, Schmitt CJ, Blazer VS, Denslow ND, Bartish TM, Anderson PJ, Coyle JJ, Dethloff GM, Tillitt DE. 2006. Environmental contaminants and biomarker responses in fish from the Columbia River and its tributaries: Spatial and temporal trends. Sci Total Environ 366:549-578.

35. Hinck JE, Blazer VS, Denslow ND, Echols KR, Gross TS, May TW, Anderson PG, Coyle JJ, Tillitt DE. 2007. Chemical contaminants, health indicators, and reproductive biomarker responses in fish from the Colorado River and its tributaries. Sci Total Environ 378:376-402.

36. Hinck JE, Blazer VS, Denslow ND, Echols KR, Gale RW, Wieser C, May TW, Ellersieck M, Coyle JJ, Tillitt DE. 2008. Chemical contaminants, health indicators, and reproductive biomarker responses in fish from rivers in the southeastern United States. Sci Total Environ 390:538-557.

37. Schmitt CJ, Blazer VS, Dethloff GM, Tillitt DE, Gross TS, Bryant WL Jr, DeWeese LR, Smith SB, Goede RW, Bartish TM, Kubiak TJ. 1999. Biomonitoring of Environmental Status and Trends (BEST) Program: Field procedures for assessing the exposure of fish to environmental contaminants. Information and Technology Report, USGS/BRD-1999-000-7. U.S. Geological Survey, Biological Resources Division, Columbia, MO.

38. Long JM, Fisher WL. 2001. Precision and bias of largemouth, smallmouth, and spotted bass ages estimated from scales, whole otoliths, and sectioned otoliths. N Am J Fish Manag 21:636-645.

39. Luna LG. 1992. Histopathologic Methods and Color Atlas of Special Stains and Tissue Artifacts. American Histolabs, Rockville, MD.

40. Denslow ND, Chow MC, Kroll KJ, Green L. 1999. Vitellogenin as a biomarker of exposure for estrogen or estrogen mimics. Ecotoxicology 8:385-398.

41. Sower SA, Schreck SB. 1982. Steroid and thyroid hormones during sexual maturation of coho salmon (Oncorhynchus kisutch) in seawater or fresh water. Gen Comp Endocrinol 47:42-53. 
42. Purdom CE, Hardiman PA, Bye VJ, Eno NC, Tyler CR, Sumpter JP. 1994. Estrogenic effects of effluents from sewage treatment works. Chem Ecol 8:275-285.

43. Liney KE, Jobling S, Shears JA, Simpson P, Tyler CR. 2005. Assessing the sensitivity of different life stages for sexual disruption in roach (Rutilus rutilus) exposed to effluent from wastewater treatment plants. Environ Health Perspect 113:1299-1307.

44. Woodling JD, Lopez EM, Maldonado TA, Norris DO, Vajda AM. 2006. Intersex and other reproductive disruption of fish in wastewater effluent dominated Colorado streams. Comp Biochem Physiol C Toxicol Pharmacol 144:10-15.

45. Aerni H-R, Kobler B, Rutishauser BV, Wettstein FE, Fischer R, Giger W, Hungerbühler A, Marazuela MD, Peter A, Schönenberger R, Vögeli AC, Suter MJ-F, Eggen RIL. 2004. Combined biological and chemical assessment of estrogenic activities in wastewater treatment plant effluents. Anal Bioanal Chem 378: 688-696.

46. Ankley GT, Brooks BW, Hugget DB, Sumpter JP. 2007. Repeating history: Pharmaceuticals in the environment. Environ Sci Technol 41:8211-8217.

47. Krisfalusi M, Nagler JJ. 2000. Induction of gonadal intersex in genotypic male rainbow trout (Oncorhynchus mykiss) embryos following immersion in estradiol-17ß. Mol Reprod Dev 56:495501

48. Tyler CR, Jobling S, Sumpter JP. 1998. Endocrine disruption in wildlife: A critical review of the evidence. Crit Rev Toxicol 28: 319-361.

49. Jobling S, Beresford N, Nolan M, Rodgers-Gray T, Brighty GC, Sumpter JP, Tyler CR. 2002. Altered sexual maturation and gamete production in wild roach (Rutilus rutilus) living in rivers that receive treated sewage effluents. Biol Reprod 66:272-281.

50. Solé M, Raldua D, Barceló D, Porte C. 2003. Long-term exposure effects in vitellogenin, sex hormones, and biotransformation enzymes in female carp in relation to a sewage treatment works. Ecotoxicol Environ Saf 56:373-380.

51. Ma T, Wan X, Huang Q, Wang Z, Lui J. 2005. Biomarker responses and reproductive toxicity of the effluent from a Chinese large sewage treatment plant in Japanese medaka (Oryzias latipes). Chemosphere 59:281-288.

52. Zhang S, Sun Y, Pang Q, Shi X. 2005. Hemagglutinating and antibacterial activities of vitellogenin. Fish Shellfish Immunol 19: 93-95.

53. Thorpe KL, Benstead R, Hutchinson TH, Tyler CR. 2007. Associations between altered vitellogenin concentrations and adverse health effects in fathead minnow (Pimephales promelas). Aquat Toxicol 85:176-183.

54. Schmid T, Gonzalez-Valero J, Rufli H, Dietrich DR. 2002. Determination of vitellogenin kinetics in male fathead minnows ( $P$ imephales promelas). Toxicol Lett 131:65-74.

55. Todd BL, Rabeni CF. 1989. Movement and habitat use by streamdwelling smallmouth bass. Trans Am Fish Soc 118:229-242.

56. Gunderson Van Arnum CJ, Buynak GL, Ross JR. 2004. Movement of smallmouth bass in Elkhorn Creek, Kentucky. N Am J Fish Manag 24:311-315.

57. Rosenblum PM, Brandt TM, Mayes KB, Hutson P. 1994. Annual cycles of growth and reproduction in hatchery-reared Florida largemouth bass, Micropterus salmoides floridanus, raised on forage or pelleted diets. J Fish Biol 44:1045-1059.

58. Gross TM, Wieser CM, Sepúlveda MS, Wiebe JJ, Schoeb TR Denslow ND. 2002. Characterization of annual reproductive cycles for pond-reared Florida largemouth bass Micropterus salmoides floridanus. Am Fish Soc Symp 31:205-212.

59. Yambe H, Munakata A, Aida K, Fusetani N, Kitamura S. 2004. Reproductive cycle of smallmouth bass in Lake Akimoto. Nippon Suisan Gakkaishi 70:896-901.

60. Tyler CR, Sumpter JP. 1996. Oocyte growth and development in teleosts. Rev Fish Biol Fish 6:287-318.

61. Miller DH, Jensen KM, Villeneuve DL, Kahl MD, Makynen EA, Durhan EJ, Ankley GT. 2007. Linkage of biochemical responses to population-level effects: A case study with vitellogenin in the fathead minnow (Pimephales promelas). Environ Toxicol Chem 26:521-527.

62. Thomas PM, Foster GD. 2005. Tracking acidic pharmaceuticals, caffeine, and triclosan through the wastewater treatment process. Environ Toxicol Chem 24:25-30.

63. Maryland Department of the Environment. 2007. Refinement of nitrogen removal from municipal wastewater treatment plants. Baltimore, MD, USA.

64. Zhan W, Xu Y, Li AH, Zhang J, Schramm K-W, Kettrup A. 2000. Endocrine disruption by hexachlorobenzene in crucian carp ( $\mathrm{Car}$ assius auratus gibelio). Bull Environ Contam Toxicol 65:560566.

65. Agency for Toxic Substances and Disease Registry. 2002. Toxicological Profile for Hexachlorobenzene (Update). Public Health Service, U.S. Department of Health and Human Services, Atlanta, GA.

66. Hayes TB, Stuart AA, Mendoza M, Collins A, Noriega N, Vonk A, Johnston G, Liu R, Kpodzo D. 2006. Characterization of atrazine-induced gonadal malformations in African clawed frogs (Xenopus laevis) and comparisons with effects of an androgen antagonist (cyproterone acetate) and exogenous estrogen (17 $\beta$ estradiol): Support for the demasculinization/feminization hypothesis. Environ Health Perspect 114:134-141.

67. Bringolf RB, Belden JB, Summerfelt RC. 2004. Effects of atrazine on fathead minnow in a short-term reproduction assay. Environ Toxicol Chem 23:1019-1025.

68. Hall LW Jr, Anderson RD, Kilian J, Tierney DP. 1999. Concurrent exposure assessments of atrazine and metolachlor in the mainstem, major tributaries and small streams of the Chesapeake Bay Watershed: Indicators of ecological risk. Environ Monit Assess 59:155-190.

69. Länge R, Hutchinson TH, Croudace CP, Siegmund F, Schweinfurth H, Hampe P, Panter GH, Sumptor JP. 2001. Effects of the synthetic estrogen $17 \alpha$-ethinylestradiol on the life cycle of the fathead minnow (Pimephales promelas). Environ Toxicol Chem 20:1216-1227.

70. Örn S, Holbech H, Madsen TH, Norrgren L, Petersen GI. 2003. Gonad development and vitellogenin production in zebrafish ( $D a$ nio rerio) exposed to ethinylestradiol and methyltestosterone. Aquat Toxicol 65:397-411. 